УДК 811.133.1'42:82-3 (045)

DOI https://doi.org/10.26661/2414-1135-2021-84-32

\title{
ЛІНГВОНАРАТИВНА СТРАТЕГІЯ «ГРА» ТА ЇЇ КОНЦЕПТУАЛІЗАЦІЯ У ФРАНЦУЗЬКОМУ ХУДОЖНЬОМУ ТЕКСТОТВОРЕННІ ХVII СТОЛІТТЯ
}

\author{
Савчук P. I. \\ доктор філологічних наук, професор, \\ завідувач кафедри іспанської та франиузької філології \\ Київський національний лінгвістичний університет \\ вул. Велика Васильківська, 73, Київ, Украӥна \\ orcid.org/0000-0001-8335-1639 \\ ruslana.savchuk11@gmail.com
}

\author{
Ключові слова: гра, \\ гомодієгетичний оповідач, \\ гетеродієгетичний \\ оповідач, кониепт, \\ модальність, просторовість, \\ темпоральність, художній \\ наратив, художне \\ текстотворення, фокалізачія.
}

У пропонованій статті розкрито механізми текстотвірної організації концепту ГРА як своєрідного ментального образу-конструкта, що домінує у французькій мовотворчості XVIII століття і відтворює специфіку французького світовідчування досліджуваного періоду, зважаючи на те, що стиль доби, її естетика й філософія відбиваються на мовотворчих індивідуальних пошуках письменників. Загальнонауковим методологічним підгрунтям пропонованої розвідки $\epsilon$ поєднання традиційного шляху дослідження художнього наративу, що реалізується через міцний зв'язок між лінгвістикою тексту і лінвостилістикою та сучасними методологічними принципами лінгвонаратології, когнітивної лінгвістики, лінгвосеміотики. Концептуально значущим постає також положення про те, що текстотвірна діяльність письменника реалізується в художньому наративі шляхом свідомого авторського вибору і застосування окремих наративних засобів і прийомів, технік і тактик для побудови певного типу оповідної реальності. У процесі цієї студії виявлено та проаналізовано найбільш показові лінгвонаративні i лінгвокогнітивні механізми конструювання дзеркальної оповідної реальності, віднайдені у французькому художньому текстотворенні XVIII століття. Було з'ясовано, що лінгвокогнітивна наративна стратегія «гра» концептуалізується в художньому наративі XVIII століття інваріантними засобами граматичного та лексичного рівнів, які найбільш повно представляють особливості творення дзеркальної оповідної реальності, що грунтується на грі письменника із часовими i просторовими координатами персонажів, а також наявністю таких семантичних опозицій, як своє / чуже, внутрішнє / зовнішнє, істинне / уявне. Серед найбільш визначальних варіантних засобів концептуалізації наративної стратегії «гра» у творенні дзеркальної оповідної реальності ми виділили метонімію, що в межах зіставлення предметів або явищ на основі їхньої суміжності звужує простір персонажного буття, акцентує увагу лише на окремих елементах або деталях, які, зважаючи на техніку частини замість цілого, форматують своєрідну просторову сітку художнього наративу (категорія просторовості). 


\title{
LINGUISTIC AND NARRATIVE STRATEGY "GAME" AND ITS CONCEPTUALIZATION IN THE 18TH CENTURY FRENCH FICTIONAL TEXT FORMATION
}

\author{
Savchuk R. I. \\ Doctor of Science (Philology), Professor, \\ Head of the Department of Spanish and French Philology \\ Kyiv National Linguistic University \\ Velyka Vassylkivska str., 73, Kyiv, Ukraine \\ orcid.org/0000-0001-8335-1639 \\ ruslana.savchuk11@gmail.com
}

Key words: game, homodiegetic narrator, heterodiegetic narrator, concept, modality category, space category, temporality category, literary narrative, fictional text formation, focalization.
In the present research paper we have revealed the mechanisms of the textual organization of the concept GAME as a dominant mental image in the 18th century French literary creation which reflects all the specificity of the word understanding and world perception by the French at the given time. We took into account the fact that the styles of the epoch, its aesthetics and its philosophy obligatory have repercussions on the authors' individual lingual creative means choice. The methodological basis of this scientific research is the combination of the traditional study of the narrative through textual linguistics, linguistic and literary stylistics but also through the methodological principles of linguistic narratology, cognitive linguistics and linguistic semiotics. The initial point in this paper is the idea that the author's creative activity takes place in the narrative via the conscious choice made by the writer to use certain narrative means, techniques and tactics when creating the narrative reality of a certain type. We have identified and analyzed the most notorious linguistic and cognitive narrative mechanisms in the creation of the mirror narrative reality in the 18th century French narrative. We have come to the conclusion that the cognitive linguistic narrative strategy "game" is conceptualized in the 18th century narrative by the invariant means of the grammatical and lexical levels. The latter fully represent the peculiarities of the creation of the mirror narrative reality which appeared following the author's play with the characters or narrator temporal and spatial locations as well as by the presence of such semantic oppositions as mine / belonging to the other, interior / exterior, real / imaginary. Among the most exemplary variant means of the conceptualization of the narrative strategy "game" while the creation of the mirror narrative reality we have revealed the metonymy which narrows the characters or narrator space by emphasizing certain elements or details and, thus, form the spatial narrative network very particular and rather unusual.
Постановка наукової проблеми та її значення. Пильна увага науковців до розроблення проблематики дослідження механізмів організації «розумового простору» [1, с. 34] автора художнього тексту пов'язана 3 характерним для різних гуманітарних парадигм наратологічним поворотом, який зумовив актуалізацію таких напрямів у наратології, як трансжанровий і трансмедіальний (М. Баль, М. Флудернік, С. Четмен); прагматичний i риторичний (В. Бут, С. Лансер); когнітивний і метанаратологічний (М. Штейнберг, М. Ян); посткласичний (К. Брук-Роуз, Х. Міллер) і соціолінгвістичний (Д. Герман, В. Лабов) тощо. Власне залучення лінгвонаративного аналізу до вивчення семантики художнього тексту грунтується на витлумаченні останньої в такому разі як упорядкованої системи смислів або такого способу передачі й накопичення знань, якому притаманні певні прототипові правила і схеми.

Актуальність цієї наукової розвідки вбачаємо в загальній спрямованості сучасних романських текстозорієнтованих студій на розкриття специфіки категоризації та концептуалізації письменником чи поетом наративної та/або реальної дійсності засобами художнього мовлення, що дозволяє виявити характер взаємодії між мовою та художнім мисленням і простежити, яким чином 
у художньому наративі тієї або іншої історико-літературної доби об'єктивуються авторські знання про навколишній світ.

Незважаючи на потужну когнітивно-семіотичну традицію у вивченні художнього наративу загалом і найбільш показових лінгвонаративних технік і практик зокрема, дискусійними і дотепер залишаються питання, пов'язані з розкриттям глибинних текстотвірних механізмів, які перетворюють авторську словесну практику на певним чином упорядковану систему подій та/чи дій.

Мета пропонованої статті - спробувати означити й охарактеризувати найбільш прикметні лінгвонаративні механізми концептуалізації гри як однієї із провідних лінгвокогнітивних стратегій французького художнього текстотворення XVIII ст. Предмет дослідження становлять архітектоніко-композиційні, семантико-синтаксичні й образно-стилістичні наративні конфігурації французького художнього наративу XVIII ст., які ми віднайшли у творах письменників указаної історико-літературної та культурної доби.

Виклад основного матеріалу й обгрунтування отриманих результатів дослідження. Серед основних лінгвонаративних технік і тактик у французькому художньому текстотворенні XVIII ст. виокремлюємо передусім тенденцію до творення ілюзї, що полягає в застосуванні письменниками доби Просвітництва таких лінгвонаративних прийомів у конструюванні оповідної реальності, які вможливлюють побудову своєрідного ігрового мікрокосму, наповненого елементами дзеркальності, як деякого іншого / інакшого світу, як певної подібності або аналогії до чогось, що вже існує.

У художніх наративах розглядуваної нами епохи формується своєрідна дзеркальна оповідна реальність, текстотвірними формантами якої $\epsilon$ «гра» і «дзеркало», а тому цілком доречно розглядати останні в термінах концеептів, оскільки вони постають особливими розумовими образами-конструктами, що домінують у французькій мовотворчості XVIII ст., а отже, найбільш повно відтворюють всю специфіку французького світобачення і світосприйняття цього періоду. Лінгвокогнітивні наративні стратегії втілені в художньому творі цієї історико-літературної доби концептами ГРА і ДЗЕРКАЛО, що вербалізовані засобами граматичного та лексико-семантичного рівнів і можуть бути співвіднесені з такими категоріями художнього наративу, як голос і темпоральність, які формують ядро концептів, та модальність і просторовість, які розміщуються на ближній і дальній периферії відповідно.

Як одна 3 найбільш показових лінгвокогнітивних стратегій у художньому текстотворенні XVIII ст. гра активізує схильність людини до наслідування, уподібнення або повторення
[2, с. 6]. Художній твір у такому разі постає «умовно віртуальним ігровим майданчиком» [там само, с. 6], який, актуалізуючи властивості дзеркала, грунтується на таких когнітивних операціях, як наслідування, уподібнення й повторення.

У художньому текстотворенні XVIII ст. ігрові тенденцї відформатовані та зреалізовані через конструювання і текстуалізацію своєрідного простору замкненості гомо- або гетеродієгетичного оповідача на особливостях персонажного буття, що вибудовує власну оповідь і водночас розповідає про деякого героя, який перетворюється на ii головного актанта, переймає на себе роль наративного суб'єкта. У когнітивно-наративній сценографії прозових текстів XVIII ст. домінує об'єктивно-суб'єктивна оповідь, яка нагадує структуру твору зі вставними епізодами (roman à tiroirs) [3] 3 огляду на те, що гомодієгетичний оповідач позиціонує себе в оповіді, однак уже згодом персонаж або персонажі перебирають на себе функцію ведення останньої.

Лінгвокогнітивна наративна стратегія «гра» має у своїй основі прийоми творення гри письменника із часовими координатами персонажів (категорія темпоральності), а також такі семантичні опозиції, як своє / чуже, внутрішнє / зовнішнє, істинне / уявне (категорія модальності). Варіантним засобом концептуалізації наративної стратегії «гра»є метонімія, що в межах зіставлення предметів або явищ на основі їхьої суміжності звужує простір персонажного буття, акцентує увагу лише на окремих елементах або деталях, які, зважаючи на техніку частини замість цілого, форматують своєрідну просторову сітку художнього наративу (категорія просторовості).

Дзеркальна двоїстість, притаманна мистецтву XVIII ст., органічно пронизує роман абата Прево "Manon Lescaut", вибудовує водночас таку оповідну реальність, яка відзначається грою із часом i простором 3 огляду на наявність у творі таких семантичних опозицій, як своє / чуже, внутрішнє / зовнішне, істинне / уявне.

Концепт ГРА традиційно посідає одне із провідних місць у французькій картині світу й характеризується багатовекторністю, зважаючи на основні тлумачення цього поняття як «деякої дії або діяльності з розважальною, а іноді й навчальною метою» [4].

Ми розглядаємо гру з позицій літературної текстотвірної практики, а тому акцентуємо увагу на такому ії визначенні, як “ensemble des mouvements des choses ou des êtres produisants un effet agréable ou curieux, ou libre exercice de quelque chose" [5] («сукупність дій предметів або об'єктів, які характеризуються приємним / цікавим результатом, або довільне використання якихось засобів» (переклад наш $-P$. C.)). 
У цьому разі саме через довільне застосування ("libre exercice de quelque chose") французькими письменниками XVIII ст. окремих текстотвірних технік і тактик у побудові художнього наративу реалізується концепт ГРА, ядром якого постають граматичні й лексико-семантичні засоби його втілення. Центральним смисловим компонентом концепту ГРА є дещо умовне / ілюзорне.

3 позицій наративно-інтерпретаційного підходу у прозовому творі XVIII ст. маємо текст у тексті [6, с. 66], або оповідь в оповіді (le récit enchâssé) [3], яку можемо трактувати як певний риторичний конструкт, у межах якого відмінності в кодуванні різних частин художнього наративу являють собою один із чинників авторської побудови й читацького сприйняття твору [там само, с. 66].

До ядерних номінацій концепту ГРА у французькому художньому дискурсі XVIII ст. належить передусім гомодієгетичний оповідач, який граматично втілений 1-ою особою однини і постає cnoстерігачем-медіатором, що реалізує наративну модель «Я - медіатор / провідник», оскільки дізнається про події та/чи дії, тобто міститься в оповіді, але не має жодного стосунку до останніх у дієгезисі. До того ж на певному етапі розгортання оповіді гомодієгетичний оповідач в екстрадієгетичній ситуації поступається персонажеві, що сам оповідає власну історію і являє собою гомодієгетичного оповідача в інтрадієгетичній позиції, що позначається в оповіді також займенником 1-ої особи однини је:

Je suis obligé de faire remonter mon lecteur au temps de ma vie où je rencontrai pour la première fois le chevalier des Grieux. Ce fut environ six mois avant mon départ pour l'Espagne. Quoique je sortisse rarement de ma solitude, la complaisance que j'avais pour ma fille m'engageait quelquefois à divers petits voyages, que j'abrégeais autant qu'il m 'était possible $[7$, c. 8$]$.

Гомодієгетичний оповідач, який маркується в оповіді займенником 1-ої особи однини је і темпоральними координатами теперішнього часу је suis obligé, відразу відмежовує себе від персонажів як головних актантів оповіді в минулому, уводить читача лише в контекст персонажного буття: ce fut environ six mois avant mon départ; je rencontrai pour la première fois le chevalier des Grieux. Можемо стверджувати, що в цьому разі оповідач перебуває й оповідає у теперішньому, тобто «тут i зараз» (le Présent de l'Indicatif), однак апелює до минулого, зважаючи на те, що події та/чи дії відбулися в минулому, про що свідчать минулий (le Passé Simple) або давноминулий (le Plus-que-parfait) часи:

Étant retourné à ma solitude, je ne fus point informé de la suite de cette aventure. Il se passa près de deux ans, qui me la firent oublier tout à fait, jusqu'à que le hasard me fît renaître l'occasion d'en apprendre à fond toutes les circonstances [7, c. 8].

Таке форматування оповіді загострює нашу увагу на моменті гри в тексті, що реалізується наявністю двох способів кодування текстового знання. Саме завдяки присутності позиції другого / іншого, ніж гомодієгетичний оповідач в екстрадієгетичній ситуації, способу кодування інформації наративна матриця аналізованого твору набуває тональності умовності, що і підсилює ігровий характер оповіді.

$<\ldots>$ Sa joie fut plus vive que toute expression, lorsqu'il m'eut remis à son tour. Ah! monsieur, $s$ 'écria-t-il en me baisant la main, je puis donc encore une fois vous marquer mon immortelle reconnaissance! Je lui demandai d'où il venait. Il me répondit qu'il arrivait, par mer, du Havre-de-Grâce, où il était revenu de l'Amérique peu auparavant [7, c. 8-9].

Гомодієгетичний оповідач, який розпочинає оповідь, перебуває за межами дієгезису, зважаючи на те, що він у цьому разі постає оповідачем-медіатором, оскільки опосередковано переповідає історію головного персонажа. Отже, гомодієгетичний оповідач в екстрадієгетичній ситуації представляє героя в межах зовнішньо-внутрішньої фокалізації 3 огляду на те, що у фокус бачення оповідача-медіатора потрапляють найпростіші рухи й жести персонажа, а також немає жодної інтроспекції у внутрішній світ останнього. Зовнішня оповідна перспектива вибудовується шляхом фіксації уваги гомодієгетичного оповідача на деталях зовнішності персонажа та його реакціях на події та/чи дії зовнішнього світу, як-от il était en fort mauvais équipage, beaucoup plus pâle, sa joie fut plus vive.

Дейктичні елементи суб'єктивної модальності, подаючи конкретну текстову ситуацію через ставлення гомодієгетичного оповідача в екстрадієгетичній ситуації до того, що він сприймає, формують додатковий внутрішній фокус бачення. Саме за допомогою лексичних одиниць 3 оціночним значенням або семантикою узагальнення / коментування в художньому наративі імпліковано концепт ГРА.

Оповідь гомодієгетичного оповідача-медіатора подано у формах непрямого мовлення $a h$ ! monsieur, s'écria-t-il en me baisant la main, je puis donc encore une fois vous marquer mon immortelle reconnaissance! Je lui demandai d'où il venait. Il me répondit qu'il arrivait, par mer, du Havre-de-Grâce, où il était revenu de l'Amérique peu auparavant, зважаючи на те, що спочатку головний актант оповіді де Гріє розповідає оповідачеві-медіатору свою історію кохання, лише після чого події та/чи дії переповідаються оповідачем, проходячи, таким чином, подвійне перетворення (ефект дзеркала, що подає відображення реальності не як реальну даність, а як деяку відтворену даність). 
Водночас реалістичність оповідного зображення поглиблюється введенням у художній наратив топонімів (il arrivait, par mer, du Havre-deGrâce, où il était revenu de l'Amérique), які дещо модифікують концепт ГРА, оскільки сполучають фрагменти описово-документального типу [8, с. 159] 3 контекстом внутрішнього персонажного буття, про що свідчить портретна характеристика головного актанта оповіді, зроблена оповідачем-медіатором: il était en fort mauvais équipage, et beaucoup plus pâle que le ne l'avais vu la première fois, що вирізняється промовистою «ощадністю» у використанні образних засобів [там само].

Вербалізація концепту ГРА відбувається також завдяки тенденції оповіді XVIII ст. до «мініатюризаціï» [9, с. 84], тобто зменшення архітектонічних об'ємів оповідної реальності як наміру «уникнути» громіздкості в масштабах жанрових конструкцій і їхньої внутрішньої композиції [там само]. Саме таким способом формується своєрідна просторова сітка в художньому наративі доби Просвітництва.

У цьому контексті серед найбільш визначальних варіантних засобів концептуалізації наративної стратегії «гра» у творенні дзеркальної оповідної реальності виокремлюємо такий троп, як метонімія, оскільки метонімічне зіставлення предметів або явищ грунтується на суміжності останніх, тобто приналежності ї до спільного кола явищ, понять або ідей, які пов'язані часовими, просторовими або причинно-наслідковими відношеннями.

У художньому наративі XVIII ст. метонімія місця репрезентативно звужує простір персонажного буття, акцентує увагу лише на окремих елементах або деталях, які, зважаючи на техніку частини замість цілого, формують і форматують загалом просторову сітку художнього наративу. Уважаємо, що саме застосування техніки метонімії в цьому сенсі вибудовує «інтер'єрний розвиток» [там само, с. 83] оповідного зображення 3 особливою значущістю «аксесуарів» або деяких моментів приватного персонажного буття. Наприклад. у художньому наративі французького письменника XVIII ст. Алена-Рене Лесажа "Le Diable boiteux" маємо яскраві приклади використання автором метонімії для творення своєрідного замкненого простору перебування головних персонажів, який, у свою чергу, як основний аксесуар їхного буття дає змогу письменнику «виписувати» характер і сутність останніх.

Висновки. Французьке художнє текстотворення XVIII ст. схарактеризоване наявністю ігрових тенденцій, які $є$ відформатованими шляхом конструювання своєрідної замкненості гомо- або гетеродієгетичного оповідача (категорія голосу) на особливостях персонажного буття. Оповідач вибудовує власну оповідь і водночас розповідає про деякого героя, який згодом переймає на себе роль наративного суб' єкта.

Лінгвокогнітивна наративна стратегія «гра» має у своїй основі прийоми творення гри письменника із часовими координатами персонажів (категорія темпоральності), а також такі семантичні опозиції, як своє / чуже, внутрішнє / зовнішне, істинне / уявне (категорія модальності). Варіантним засобом концептуалізації наративної стратегії «гра» є метонімія, що в межах зіставлення предметів або явищ на основі їхньої суміжності звужує простір персонажного буття, акцентує увагу лише на окремих елементах або деталях, які, зважаючи на техніку частини замість цілого, форматують своєрідну просторову сітку художнього наративу (категорія просторовості).

Результати цієї розвідки дають змогу вбачати перспективи подальшого дослідження лінгвонаративних стратегій текстотворення в інших франкомовних дискурсивних практиках.

\section{ЛІТЕРАТУРА}

1. Архипов И.К. Природа концепта и методы его изучения. Концептуальный анализ языка: современные направления исследования : сборник научных трудов / отв. ред. Е.С. Кубрякова. Москва ; Калуга : ИП Кошелев А.Б. ; Эйдос, 2007. C. 33-42.

2. Пікун Л.В. Дзеркальна гра набутками культури: романтична та постмодерністська модель (на матеріалі романів М. Шеллі «Франкенштейн, або сучасний Прометей» i П. Зюскінда «Парфуми: історія одного вбивці» : автореф. дис. ... канд. філол. наук : 10.01.04. Київ, 2006. 22 с.

3. Éléments de narratologie. URL: http:// emile.simonnet.free.fr/sitfen/narrat/ discours.htm (дата звернення: 24.09.2021).

4. Словник української мови : в 11-и т. (1970-1980). Академічний тлумачний словник. URL: http:// sum.in.ua (дата звернення: 24.09.2021).

5. Dictionnaire encyclopédique, chronologie, animations et ressources pédagogiques interactives. URL: www.larousse.fr (дата звернення: 24.09.2021).

6. Лотман Ю.М. Семиосфера. Санкт-Петербург : Искусство-СПб, 2000. 704 с.

7. Marivaux P.C. de Chamblain. La Vie de Marianne. Paris : Éditions Gallimard, 1997. 778 p. URL: www.gallica.bnf.fr (дата звернення: 24.09.2021).

8. Бублейник Л.В. Особливості художнього мовлення : навчальний посібник зі спеціального курсу для студентів гуманітарних факультетів. Луцьк : РВВ «Вежа» ВДУ ім. Лесі Українки, 2000. 177 с. 
9. Пахсарьян Н.Т. Избранные статьи о французской литературе : монография. Днепропетровск : Арт-Пресс, 2010. 256 с.

\section{REFERENCES}

1. Arkhipov, I.K. (2007). The nature of the concept and methods of its study [Priroda koncepta i metody ego izuchenija]. Konceptual'nyj analiz jazyka: sovremennye napravlenija issledovanija. Moscow ; Kaluga, pp. 33-42.

2. Pikun, L.V. (2006). Mirror Play with Cultural Heritage: Romantic and Postmodern Models (based on "Frankenstein or, the Modern Prometheus" by M. Shelley and "Das Parfum. Die Geschichte eines Mörders” by P. Süskind) [Dzerkaljna ghra nabutkamy kuljtury: romantychna ta postmodernistsjka modelj (na materiali romaniv M. Shelli "Frankenshtejn, abo suchasnyj Prometej" i P. Zjuskinda "Parfumy: istorija odnogho vbyvci"]. (Thesis for a Candidate of Philology degree). Kyiv National Linguistic University, Kyiv.
3. Éléments de narratologie. Retrieved from http:// emile.simonnet.free.fr/sitfen/narrat/discours.htm.

4. Dictionary of the Ukrainian language in 11 volumes. (1970-1980). Academic explanatory dictionary. Retrieved from http://sum.in.ua.

5. Dictionnaire encyclopédique, chronologie, animations et ressources pédagogiques interactives. Retrieved from www.larousse.fr.

6. Lotman, Yu.M. (2000). Semiosphere [Semiosphere]. Saint Petersburg : Art-SPb.

7. Marivaux P.C. de Chamblain. (1997). La Vie de Marianne. Paris : Éditions Gallimard. Retrieved from www.gallica.bnf.fr.

8. Bubleynyk, L.V. (2000). Peculiarities of artistic speech [Osoblyvosti khudozhnjogho movlennja]. Lutsk : Editorial and Publishing Department "Vezha".

9. Pakhsaryan, N.T. (2010). Selected articles on French literature [Izbrannye stat'i o francuzskoj literature]. Dnepropetrovsk : Art-Press. 